\title{
Inclusion of fermented fish by-product silage in the diets of the Nile tilapia, Oreochromis niloticus
}

\author{
Mohamed Y. Abou Zead ${ }^{1}$ and Magdy A. Soltan ${ }^{2}$ \\ 1- World Fish, Abbassa, AbouHammad, Sharkia, Egypt. \\ 2- Faculty of Agriculture, Benha University, Egypt.
}

\section{ABSTRACT}

A feeding trial was conducted to study the possibility of replacing the fish meal (FM) with fermented fish by-product silage (FBS) as non-conventional ingredients in the diets of the Nile tilapia, Oreochromis niloticus fingerlings. Five isonitrogenous (300 g CP $\mathrm{kg}^{-1}$ dry matter, DM) and isocaloric (19 MJ gross energy kg-1 DM) diets were formulated and FM was replaced by FBS in five increased levels, 0, 25, 50, 75 and $100 \% \mathrm{~g}$ to formulate the five experimental diets, FBS0, FBS25, FBS50, FBS75 and FBS100, respectively. Three hundred $O$. niloticus fingerlings $(18.53 \pm 0.70 \mathrm{~g})$ were randomly distributed into 15 glass aquaria (160 liter), and were divided into five groups (three aquaria for each group) and each aquarium holding 20 fish. Experimental fish were fed onon the formulated diets for 84 days. Replacing of FM with FBS up to $25 \%$ did not significantly $(\mathrm{P}<0.05)$ affected growth and feed utilization parameters, while the other substitution levels $(50,75$ or $100 \%)$ significantly $(\mathrm{P}<0.05)$ reduced growth and feed utilization parameters. Fish offered the control diet exhibited the highest significance $(\mathrm{P}<0.05)$ average body weight $(\mathrm{BW})$, body length $(\mathrm{BL})$, weight gain $(\mathrm{WG})$, specific growth rate (SGR), feed conversion ratio (FCR) and protein efficiency ratio (PER). Fish group fed onon FBS25 gained the highest significant protein content and the lowest fat and ash content of carcasses compared to the control and the other fish groups Generally, replacing $25 \%$ of FM by FBS did not significantly affected growth and feed utilization parameters and reduced feed costs by $7.93 \%$ for tilapia fingerlings.

Keywords: Fermented silage, fish meal, Oreochromis niloticus

\section{INTRODUCTION}

The current fishmeal usage in aquafeeds is becoming unsustainable as aquaculture production continues to expand. Cost is also a major constraint to production with greater requirements for more strategic use of this commodity in feeds. This exacerbates pressures on wild fisheries which cannot be sustained to meet such demands (Hassaanet al., 2015). Traditionally, alternatives to protein meals have been sought from vegetable sources such as soybean meals (Soltanet al., 2001), cottonseed meals (Abdellaet al., 2008 and Soltanet al. $2011 \mathrm{a} \& \mathrm{~b}$ ), sunflower meal (Soltanet al., 2015), linseed and canola seed meals (Soltan, $2005 \mathrm{a} \& \mathrm{~b}$ ) due to their wide spread availability, relatively favorable amino acid profiles, reduced cost and sustainable nature (Hardy, 2010). However, the inclusion of plant based proteins in aquafeeds provides a number of problems which include the occurrence of antinutritional factors, reduced digestibility, lower palatability and limitations of certain essential amino acids (Oliva-Teles and Gonçalves, 2001).

By-products or fish wastes are those non-edible parts of the fish body. They include fish head, skin, bones, fins, scales and viscera, which includes gonads, intestine and liver. After some processing, fish wastes represent a good protein source for fish 
due to its high contents of fish protein containing the essential amino acids (Hafez et al., 2000).

During recent years there has been increased interest in the use of enzymatic stabilization techniques for the preservation and utilization of feed materials for animal feeding. A great deal of attention has been concentrated on the utilization of fish by-products, including low grade industrial fish species, filleting waste and bycatch. It has been possible to treat terrestrial animal by-products using ensiling techniques (Norman et al., 1979). Silage production is possible by lactic acid bacterial fermentation. To undergo proper fermentation the raw material must contain lactic acid bacteria, a suitable nutritional substrate for the bacteria and a temperature compatible with rapid growth. Although lactic acid bacteria are invariably present in the raw material and a starter culture is not required (Kompiang et al., $1980 \mathrm{a \& b}$ ) the inoculation of material with fermented starter culture is recommended. Soltan and Tharwat (2006) indicated that fermented fish silage can successfully replace up to $50 \%$ of fish meal in African catfish, Claris gariepinus diets without adverse effect on growth performance or feed utilization.

The aim of this study was to evaluate the possibility of replacing of fish meal by silage made from fish by-product on growth performance, feed utilization and proximate composition of the Nile tilapia, $O$. niloticus fingerlings.

\section{MATERIALS AND METHODS}

\section{Preparation of fermented fish silage (FBS):}

Fish by-products (non edible parts) were obtained from El-Obour market and minced. FBS was prepared by mixing the minced fish by-products $(60 \%)$, rice bran (30\%), dried molasses (5\%) as a source of carbohydrate (energy) and 5\% yogurt (as a source of Lactobacillus spp. for lactic acid anaerobic fermentation process).Potassium sorbate solution (1\%) as antimicrobial agent was sprayed and the mixture was packed in black polyethylene bags. All bags were incubated in tightly hard plastic container and stored at ambient temperature that ranged from 30 to $38^{\circ} \mathrm{C}$. The ensilage process completed after 30 days and at the end, a liquid FBS of pH 4.5 was obtained and sundried for 3 days. The resultant dried FBS had brownish color and strong fish odor and contained $38.12 \%$ crude protein $(\mathrm{CP})$.

\section{Experimental diets}

The experiment was conducted at the experimental facilities of the Fish Nutrition Lab, Department of Animal Production, Faculty of Agriculture, Benha University, Egypt. Five isonitrogenous (300 $\mathrm{g} \mathrm{CP} \mathrm{kg}^{-1}$ dry matter, DM) and isocaloric (19 MJ gross energy $\mathrm{kg}^{-1} \mathrm{DM}$ ) diets were formulated and fish meal was replaced by fermented fish byproducts silage at increasing levels of $0,25,50,75$ and 100\% representing the five diets, FBS0, FBS25, FBS50, FBS75 and FBS100, respectively.

All dry ingredients of the fish meal, soybean meal, yellow corn and wheat bran were blended for $5 \mathrm{~min}$ and thoroughly mixed with soybean oil and vitamin and mineral mixture (Table 1). The ingredients were mixed well and made into dry pellets using a laboratory pellet mill (California Pellet Mill, San Francisco, CA, USA). The pellets (1mm diameter) were dried for $4 \mathrm{~h}$ at $60^{\circ} \mathrm{C}$ and stored at $-20^{\circ} \mathrm{C}$ until use.

\section{Experimental Fish and Facilities}

The Nile tilapia, Oreochromis niloticus fingerlings were obtained from Abbassa hatchery, Sharkia Governorate, Egypt. Fish were transferred in 50-liter plastic bags filled with water and oxygen to fish Lab. Prior to the beginning of the experiment; fish were acclimatized to the experimental conditions and fed onon commercial diet (300 g protein 
$\mathrm{kg}^{-1}$ ) twice daily to apparent satiation by hand for 15 days. After acclimatization, fingerlings $(18.53 \pm 0.70 \mathrm{~g})$ were stocked into fifteen glass aquaria $(160 \mathrm{~L})$. Three replicate aquaria were randomly assigned to each treatment and each aquarium was stocked with 20 fish.

Table 1: Composition and chemical analysis of the experimental diets.

\begin{tabular}{|c|c|c|c|c|c|}
\hline \multirow[b]{2}{*}{ Feed ingredients } & \multicolumn{5}{|c|}{ Experimental diets } \\
\hline & Diet & Diet & Diet & Diet & Diet \\
\hline Fish meal $(65 \%)$ & 20 & 15 & 10 & 5 & 0 \\
\hline Fermented fish silage & 0 & 10 & 20 & 30 & 40 \\
\hline Soybean meal & 47 & 47 & 47 & 48 & 48 \\
\hline Yellow corn & 18 & 18 & 16 & 10 & 5 \\
\hline Wheat bran & 9 & 4 & 1 & 1 & 1 \\
\hline Vegetable oil & 3 & 3 & 3 & 3 & 3 \\
\hline Vit. \& Min. mixture ${ }^{1}$ & 3 & 3 & 3 & 3 & 3 \\
\hline \multirow[t]{2}{*}{ Sum } & 100 & 100 & 100 & 100 & 100 \\
\hline & & \multicolumn{4}{|c|}{ Chemical analysis (determined on dry matter basis) } \\
\hline Dry matter $(\mathrm{DM})$ & 94.52 & 95.11 & 94.78 & 95.05 & 93.98 \\
\hline Crude protein $(\mathrm{CP})$ & 30.33 & 30.18 & 30.22 & 30.80 & 30.49 \\
\hline Ether extract (EE) & 6.15 & 6.16 & 6.54 & 5.97 & 6.16 \\
\hline Crude fiber $(\mathrm{CF})$ & 5.56 & 5.25 & 5.67 & 6.38 & 6.36 \\
\hline Ash & 8.55 & 8.45 & 8.86 & 8.66 & 8.46 \\
\hline $\mathrm{NFE}^{2}$ & 49.41 & 49.96 & 48.71 & 48.19 & 48.53 \\
\hline Gross energy $\left(\mathrm{MJ} \mathrm{kg}^{-1} \text { diet }\right)^{3}$ & 19.02 & 19.03 & 19.05 & 19.00 & 19.04 \\
\hline
\end{tabular}

${ }^{1}$ Vitamin \& mineral mixture/kg premix: Vitamin $\mathrm{D}_{3}, 0.8$ million IU; A, 4.8 million IU; E, 4 g; K, 0.8 g; B1, 0.4 g; Riboflavin, 1.6 g; B6, 0.6 g, B12, 4 mg; Pantothenic acid, 4 g; Nicotinic acid, 8 g; Folic acid, 0.4 g Biotin,20 mg , Mn, 22 g; Zn, 22 g; Fe, 12 g; Cu, 4 g; I, 0.4 g, Selenium, 0.4 g and Co, 4.8 $\mathrm{mg}$.

${ }^{2}$ Nitrogen free extract $(\mathrm{NFE})=100-(\mathrm{CP}+\mathrm{EE}+\mathrm{CF}+\mathrm{Ash})$

${ }^{3}$ Gross energy calculated using gross calorific values of $0.2363,0.3952$ and $0.1715 \mathrm{MJ} / \mathrm{g}$ for protein, fat and carbohydrate, respectively according to Brett (1973).

The glass aquaria were supplied with de-chlorinated tap water and were continuously supplied with compressed air. About one-third of the water volume in each aquarium was daily replaced by new aerated fresh water after cleaning and removing of the accumulated excreta. A photoperiod of $12 \mathrm{~h}$ light, $12 \mathrm{~h}$ dark (08.00 to 20.00) was used.

Fluorescent ceiling lights has supplied the illumination. Fish were fed onon their respective diets by hand one of eight experimental diets for 84 days. Tilapia fry fed onon the pelleted diets ( $1 \mathrm{~mm}$ in diameter) at a daily rate of $10 \%$ (during the $1^{\text {st }}$ month), then gradually decreased to $7 \%$ ( $2^{\text {nd }}$ month) and $4 \%$ ( $3^{\text {rd }}$ month $)$ of total biomass 6 day/week (twice daily at 9.00 am and $3.00 \mathrm{pm}$ ) and the amount of feed was bi-weekly adjusted according to the changes in body weight.

Water temperature, dissolved oxygen, $\mathrm{pH}$, and total ammonia were monitored during the study, to maintain water quality at optimal range for the Nile tilapia. Dissolved oxygen (DO) and water temperature were measured daily at $11.00 \mathrm{~h}$ using YSI model 56 oxygen meter (YSI Company, Yellow Springs Instrument, Yellow Springs, Ohio, USA) and $\mathrm{pH}$ was recorded daily at $12.00 \mathrm{~h}$ using a $\mathrm{pH}$ meter (Orion $\mathrm{pH}$ meter, Abilene, Texas, USA). Total ammonia was weekly measured according to APHA (1992). During the period of the feeding trial, the water-quality parameters were averaged $( \pm \mathrm{SD})$ : water temperature was $26.43 \pm 0.5^{\circ} \mathrm{C}$ : dissolved oxygen, $7.4 \pm 0.5 \mathrm{mg} / \mathrm{L}: \mathrm{pH} 8.65 \pm 0.5$ and total ammonia, $0.11 \pm 0.04 \mathrm{mg} / \mathrm{L}$. All tested water quality criteria were suitable and within the acceptable limits for rearing the Nile tilapia, O. niloticus fingerlings (Boyd 1979). 


\section{Growth and feed utilization Indices}

Also, body weight and body length were individually measured for each aquarium at the initiation and the end of the feeding trail. Weight gain (WG), specific growth rate (SGR), feed conversion ratio (FCR) and protein efficiency ratio (PER) were calculated using the following equations:

$\mathrm{WG}(\mathrm{g} / \mathrm{fish})=F B W-I B W ; \mathrm{SGR} \%=[\ln F B W-\ln \mathrm{IBW}] / \mathrm{t} \times 100$, where $\mathrm{FBW}$ is final body weight $(\mathrm{g})$; IBW is initial body weight $(\mathrm{g}) ; \mathrm{ln}=$ natural logarithmic; $\mathrm{t}=$ time in days. $\mathrm{FCR}=F I / W G$, where $\mathrm{FI}$ is feed intake $(\mathrm{g}) ; \mathrm{PER}=W G /$ protein intake $(\mathrm{g})$.

\section{Proximate analysis of fish and experimental diets:}

At experiment termination, three fish were chosen at random from each treatment and exposed to the proximate analysis of whole fish body according to the methods of AOAC (1995). Fish and diet samples were oven-dried $105^{\circ} \mathrm{C}$ for $24 \mathrm{~h}$, ground, and stored at $-20^{\circ} \mathrm{C}$ for subsequent analysis.Dry matter was determined after drying fish samples in an oven $\left(105^{\circ} \mathrm{C}\right)$ for $24 \mathrm{~h}$. rephrase $550^{\circ} \mathrm{C}$ for 12 hour. Crude protein was determined by micro-Kjeldhal method, $\mathrm{N} \times 6.25$ (using Kjeltech auto analyzer, Model 1030, Tecator, Höganäs, Sweden) and crude fat by Soxhlet extraction with diethyl ether $\left(40-60^{\circ} \mathrm{C}\right)$. Crude fiber content of diets was determined using the method of (Van Soest et al. 1991). Nitrogen-free extract was computed by taking the sum of values for crude protein, crude lipid, crude fiber and ash then subtracting this sum from 100.

\section{Statistical analysis}

Statistical analysis of the obtained data was analyzed according to SAS (1996). Differences between means were tested for significance according to Duncan's multiple rang test as described by Duncan (1955).

\section{RESULTS AND DISCUSSION}

\section{Body weight (BW), Body length (BL) and Condition factor (K)}

At the experiment end (after 84 days form the experimental start) the highest average BW (40.14 g) was recorded for control group which fed on the diet FBS0 followed in descending order by those fed on the diet FBS25 (39.35 g), FBS75 (32.37 g), FBS50 (31.65 g), and FBS100 (30.64 g). Results of the present study indicated that substituting $25 \%$ of FM by FBS (on protein content basis) did not significantly affected the final BW and body length (BL) of the Nile tilapia, however the other levels (50, 75 or $100 \%)$ significantly $(\mathrm{P}<0.05)$ reduced the final $\mathrm{BW}$ and $\mathrm{BL}$ of the Nile tilapia. The obtained results of the two experiments indicating the possibility of replacing $25 \%$ of FM by FBS in the Nile tilapia fingerlings diets without adverse effect on the final BW (Table 2).

Table 2: Means and standard error for the effect of replacing levels of fish meal by fermented fish silage in the diets on body measurements of the Nile tilapia.

\begin{tabular}{|c|c|c|c|c|c|c|}
\hline \multirow[t]{2}{*}{ Diets } & \multicolumn{2}{|c|}{ Body weight $(\mathrm{BW}) / \mathrm{g}$} & \multicolumn{2}{|c|}{ Body length (BL)/cm } & \multicolumn{2}{|c|}{ Condition factor $(\mathrm{K})$} \\
\hline & Initial & Final & Initial & Final & Initial & Final \\
\hline FBS0 & 19.11 & $40.14 \mathrm{a}$ & 9.88 & $12.84 \mathrm{a}$ & 1.98 & $1.90 \mathrm{a}$ \\
\hline FBS25 & 18.34 & $39.35 \mathrm{a}$ & 9.92 & $13.20 \mathrm{a}$ & 1.88 & $1.73 \mathrm{~b}$ \\
\hline FBS50 & 18.62 & $31.65 \mathrm{~b}$ & 9.90 & $12.07 \mathrm{~b}$ & 1.95 & $1.80 \mathrm{ab}$ \\
\hline FBS75 & 18.45 & $32.37 \mathrm{~b}$ & 9.78 & $12.18 \mathrm{~b}$ & 1.99 & $1.79 \mathrm{ab}$ \\
\hline FBS100 & 18.13 & $30.64 \mathrm{~b}$ & 9.79 & $12.19 \mathrm{~b}$ & 1.93 & $1.70 \mathrm{~b}$ \\
\hline Standard error & 0.70 & 1.53 & 0.15 & 0.21 & 0.17 & 0.03 \\
\hline
\end{tabular}

Averages within each column having different letters are significantly different $(\mathrm{P}<0.05)$

The obtained results are in agreement with those obtained by Salah Al-Din (1995). He found that the best final body weight of catfish was obtained from fish fed 
on $30 \%$ fish silage sun or oven dried. Increasing replacing levels of FM by FBS up to $50 \%$ in the diets did not significantly affected the final BW of catfish (Soltan et al., (2008) and the Nile tilapia, O. niloticus fry (Soltan et al., 2016), while the higher replacing levels $(75$ or $100 \%)$ significantly $(\mathrm{P}<0.001)$ decreased the final $\mathrm{BW}$. In another study, Soltan and Tharwat (2006) found that replacement of FM by FBS by in the diets of the Nile tilapia up to $25 \%$ did not significantly affected the final BL after 90 days of the experimental period, while the higher replacing levels $(50,75$ or $100 \%)$ significantly decreased the final BL of the Nile tilapia.

The initial condition factor $(\mathrm{K})$ for the Nile tilapia fry ranged between 1.88 and 1.99 with insignificant differences in condition factor. At experiment termination, $\mathrm{K}$ values ranged between 1.70 to 1.90 and the differences between $\mathrm{K}$ values were significant $(\mathrm{P}<0.05)$. Compared to control group all replacing levels of FM by FBS significantly affected $\mathrm{K}$ values of the Nile tilapia fingerlings. In the study of Cavalheiro et al., (2007) the partial or complete replacement of fish meal by fermented shrimp industry wastes did not show any statistical differences in $\mathrm{K}$ values at the $5 \%$ probability levels and $\mathrm{K}$ values ranged from 1.36 to 1.83 . $\mathrm{K}$ values obtained in the present study are near the range of 1.36-1.83 for the Nile tilapia, O. niloticus (Cavalheiro et al., 2007) and 1.72 (AbouZead et al., 2008) However, Abdel-Hakim et al.(2001a) reported smaller values of 1.00 and 1.03 for the same species.

\section{Weight gain (WG) and specific growth (SGR):}

Results of Table (3) shows that, after 84 days of the experimental start, the averages of WG were found to be 21.04, 21.01, 13.03, 13.92 and $12.51 \mathrm{~g}$ and the values of SGR were $0.83,0.85,0.59,0.63$ and 0.59 for the different experimental diets FBS0, FBS25, FBS50, FBS75 and FBS100, respectively.

The highest values of WG and SGR were recorded for fish group fed on the FBS25 diet in which $25 \%$ of FM was replaced by FBS and did not significantly different from those recorded by fish group fed on the basal diet (FBS0) whatever the higher replacing levels $(50,75$ or 100\%) significantly reduced the WG and SGR of the Nile tilapia fingerlings and this may be attributed to the positive effect of balanced amino acid composition content of FM compared to FBS. Similar results were obtained by Soltan and El-Laithy (2008) who found that replacement of $30 \%$ of the dietary protein by silage did not significantly affected the final BW, WG and SGR, while the higher replacing levels (40 or $50 \%$ ) significantly reduced BW of the Nile tilapia. In another study, Wassef et al. (2003) found that replacement of 25, 50, 75 or $100 \%$ of FF by FBS alone or mixed with soybean meal $(1: 1)$ significantly $(\mathrm{P}<0.05)$ decreased the final BW of the Nile tilapia fed on $28 \%$ CP experimental diets, while WG and SGR did not significantly affected by the partial or the complete replacement of FBS alone or when mixed with soybean meal. On the other hand, Cavalheiro et al. (2007) indicated the possibility of partial or complete replacement of FM by fermented shrimp industry wastes in the diets of the Nile tilapia, $O$. niloticus without any statistical differences in the average daily gain.

Reduced growth response in the Nile tilapia fingerlings fed on diets in which FM was completely replaced FBS meal have been explained by sub-optimal amino acid balance, inadequate levels of energy and low feed intake caused by palatability. Lower growth at the complete replacement of FM by FBS in the present study may have been caused by one or some of these factors.

Results of growth performance parameters of the Nile tilapia fingerlings areillustrated in Tables ( 2 and 3) indicating that replacement of FM by FBS up to 25\% in fingerlings diets did not affected BW, BL, WG, and SGR, while the higher or the complete replacement of FM by FBS significantly $(\mathrm{P}<0.05)$ reduced these growth 
parameters. Espe et al. (1999) reported a similar effect for low inclusion levels (15\%) using fish silage in Atlantic salmon diets. Also, Plascencia-Jatomeaet al.(2002) found that, replacing FM by shrimp head silage in the Nile tilapia diets up to $15 \%$ showed the best response in growth performance, while the higher replacing levels $(20,25$ or $30 \%$ ) resulted in the worst growth response. Nwanna and Daramola (2001) found that, replacing FM by shrimp head waste meal at $0,15,30,45$ and $60 \%$ in $30 \%$ protein diets decreased final BW, WG and SGR and the decrease was more pronounced at the higher replacement levels.

The higher levels (50\% FM replacement by FBS) were reported in earlier studies of Lapie and Bigueras-Benitez (1992) who found no differences in growth performance of the Nile tilapia fed on a formic acid preserved fish silage blended with FM (1:1), and growth performance was significantly reduced when the replacing levels increased up to 75\%. Also, Fagbenro (1994) and Fagbenro et al.(1994) stated that, up to $75 \%$ of FM protein could be successfully replaced with tilapia silage and soybean meal (1:1) in 30\% $\mathrm{CP}$ diets for all male $O$. niloticus.

Jeon et al. (2014) indicated the possibility of partial substituting fish meal with tuna by-product meal up to $40 \%$ in the diet of juvenile Korean rockfish without exerting a detrimental effect on their growth (SGR). In the same trend Zhou et al.(2016) replaced fish meal (FM) with fermented meal mixture of silkworm pupae, rapeseed and wheat (FMM) in the diets of mirror carp (Cyprinus carpiovar. Specularis), and they found that, growth, feed utilization and crude lipid content were negatively correlated with FMM levels in the diet.

Table 3: Means and standard error for the effect of replacing levels of fish meal (FM) by fermented fish silage (FBS) in the diets on body weight gain (WG) and specific growth rate (SGR) of the Nile tilapia fingerlings.

\begin{tabular}{lll}
\hline Diets & Weight gain (g/fish) & Specific growth rate \\
\hline FBS0 & $21.04 \mathrm{a}$ & $0.83 \mathrm{a}$ \\
FBS25 & $21.01 \mathrm{a}$ & $0.85 \mathrm{a}$ \\
FBS50 & $13.03 \mathrm{~b}$ & $0.59 \mathrm{~b}$ \\
FBS75 & $13.92 \mathrm{~b}$ & $0.63 \mathrm{~b}$ \\
FBS100 & $12.51 \mathrm{~b}$ & $0.59 \mathrm{~b}$ \\
Standard error & 1.38 & 0.04 \\
\hline
\end{tabular}

Means followed by different letters in each column are significantly different $(\mathrm{P}<0.05)$.

\section{Feed intakeand feed utilization}

As shown this Table (4), the highest (35.92 g/fish) feed intake was recorded for fish group fed on the control diet FBS0 followed in descending order by those in groups fed on the diets FBS25 (34.34 g), FBS75 (32.50 g), FBS50 (29.83 g) and FBS100 (29.21 g) and the differences among these means were significant $(\mathrm{P}<0.05)$. Replacing FM by FBS up to $25 \%$ in the diets of the Nile tilapia fingerlings did not significantly affected FCR or PER, while the higher replacing levels, 50, 75 or $100 \%$ significantly adversed FCR and PER.

The obtained results are relatively agreed with those obtained by Plascencia-Jatomea et al. (2002) who found that, replacing FM by shrimp head silage in the Nile tilapia diets up to $20 \%$ did not significantly affected FCR or PER while the higher replacing levels (25 or 30\%) significantly adversed FCR and PER of the Nile tilapia. Fagbenro et al. (1994) found that, Oreochromis niloticus and Clarias gariepinus, fed on fish silage diets (50\% of the total dietary protein) showed a similar $(\mathrm{P}>0.05)$ FCR and PER as those of the control diet. 
Table 4: Means and standard error for the effect of replacing fish meal (FM) by fermented fish silage (FS) in the diets on Feed intake, feed utilization of the Nile tilapia fingerlings.

\begin{tabular}{lccc}
\hline Diets & $\begin{array}{c}\text { Feed intake } \\
\text { (gm/fish }\end{array}$ & $\begin{array}{c}\text { Feed conversion } \\
\text { ratio (FCR) }\end{array}$ & $\begin{array}{c}\text { Protein efficiency } \\
\text { ratio (PPR) }\end{array}$ \\
\hline FBS0 & $35.92 \mathrm{a}$ & $1.72 \mathrm{~b}$ & $1.76 \mathrm{a}$ \\
FBS25 & $34.34 \mathrm{a}$ & $1.64 \mathrm{~b}$ & $1.84 \mathrm{a}$ \\
FBS50 & $29.83 \mathrm{~b}$ & $2.30 \mathrm{a}$ & $1.33 \mathrm{~b}$ \\
FBS75 & $32.50 \mathrm{ab}$ & $2.34 \mathrm{a}$ & $1.31 \mathrm{~b}$ \\
FBS100 & $29.21 \mathrm{~b}$ & $2.35 \mathrm{a}$ & $1.33 \mathrm{~b}$ \\
Standard error & 1.12 & 0.18 & 0.12 \\
\hline
\end{tabular}

Averages within each column having different letters are significantly different $(\mathrm{P}<0.05)$,

\section{Proximate analysis:}

Results of body composition of whole fish body (Table 5) showed that, dry matter (DM) of whole fish lies in three groups, the first group; include fish fed on the diets FBS0 and FBS75 and the second group includes fish groups fed on the diets FBS25 and FBS50, while the third one includes fish group fed on the diet FBS100 and the differences between these groups were significant $(\mathrm{P}<0.05)$. The differences within each group were not significant. Fish group fed on FBS25 has been gained the highest significant protein content and the lowest fat and ash content of carcasses compared to the control and the other fish groups. In this respect Fagbenro and Jauncey (1995) found that, fermented fish silage did not significantly affected dry matter, protein, lipids and ash content of catfish, Clarias gariepinus bodies. On the other hand, Plascencia-Jatomea et al.(2002) indicated that, all replacing levels (10, 15, 20, 25 and $30 \%$ ) of FM by shrimp head silage in the Nile tilapia diets significantly affected dry matter, crude protein, ether extract and ash contents of Nile tilapia. Soltan and Tharwat (2006) showed that partial or complete replacement of FM by FBS significantly $(\mathrm{P}<0.001)$ decreased protein content and increased fat, whereas fish group fed on the control diet gained the lower protein and fat content. Mach and Nortvedt (2013) fed on two moist diets based on raw fish with or without added fish silage to Cobia, Rachycentron canadum. They found no significant differences in nutritional composition between the fillet groups, which were of high quality with a balance of essential and non-essential amino acids and medium levels of omega-3 fatty acid composition. Hernández et al. (2014) indicated that replacement of fish meal (FM) with tuna by-product meal (TBM), in diets for spotted rose snapper, Lutjanus guttatus did not significantly affected whole-body proximate composition.

Table 5: Means and standard error for the effect of replacing levels of fish meal (FM) by fermented fish silage (FBS) in the diets on proximate analysis of the Nile tilapia fingerlings.

\begin{tabular}{lcccc}
\hline Diets & Dry matter & Crude protein & Ether extract & Ash \\
\hline FBS0 & $26.42 \mathrm{~b}$ & $63.49 \mathrm{~b}$ & $16.46 \mathrm{c}$ & 19.75 \\
FBS25 & $24.74 \mathrm{c}$ & $66.13 \mathrm{a}$ & $15.20 \mathrm{bc}$ & 18.19 \\
FBS50 & $24.72 \mathrm{c}$ & $62.05 \mathrm{~b}$ & $17.14 \mathrm{a}$ & 19.75 \\
FBS75 & $26.30 \mathrm{~b}$ & $62.63 \mathrm{~b}$ & $16.22 \mathrm{~b}$ & 20.33 \\
FBS100 & $28.32 \mathrm{a}$ & $62.25 \mathrm{~b}$ & $17.76 \mathrm{a}$ & 19.03 \\
Standard error & 0.31 & 0.60 & 0.86 & 0.67 \\
\hline
\end{tabular}

Averages within each column having different letters are significantly different $(\mathrm{P}<0.05)$

\section{Economic efficiency:}

Results of the present study showed the possibility of replacing of FM by FBS up to $25 \%$ in tilapia diets without adverse effect on growth performance and feed utilization parameters. Feed cost is considered to be the highest recurrent cost in aquaculture, often more than $60 \%$, depending on the intensity of the operation (Ibrahim et al.2000 and Abdel- 
Hakim et al.2001 a \& b \& c). Any reduction in feed costs either through diet development, improved husbandry or other direct or indirect means is therefore decreased the total production investment and increased the net return (Soltan et al. 2002, Abou Zead et al. 2008). All other costs are almost constant, therefore, the feeding costs required to produce one $\mathrm{kg}$ gain in weight could be used to compare the economic efficiency of different experimental treatments.

As shown in Tables (6 and 7), feed costs (LE/ton) decreased gradually with increasing substitution level of FM by FBS. Increasing substitution level of FM by FBS at 25, 50, 75 and 100\% decreased feed costs by 7.92, 16.14, 24.31 and 32.97\%, respectively. Compared to the control diet, feed costs (LE/kg WG) decreased by $12.24 \%$ and $9.61 \%$ when 25 and $100 \%$ of FM was replaced by FBS, while replacing levels of 50 or $75 \%$ increased feed costs/kg weight gain by 12.13 and $2.93 \%$.

In conclusion, replacing $25 \%$ of fish meal by fermented fish by-product silage reduced feed costs by $7.92 \%$ and reduced feed costs (L.E)/kg weight gain by $12.24 \%$.

Table 6: Feed costs (L.E) for producing one kg weight gain by fish fed on the experimental diets.

\begin{tabular}{llcccccc}
\hline \multicolumn{1}{c}{ Diets } & $\begin{array}{c}\text { Costs } \\
\text { (L.E)/ton }\end{array}$ & $\begin{array}{c}\text { Relative to } \\
\text { control \% }\end{array}$ & $\begin{array}{c}\text { Decrease in } \\
\text { feed cost } \\
(\%)\end{array}$ & FCR & $\begin{array}{c}\text { Feed costs } * \\
\text { (L.E)/kg } \\
\text { Weight gain }\end{array}$ & $\begin{array}{c}\text { Relative to } \\
\text { control \% }\end{array}$ & $\begin{array}{c}\text { Decrease in } \\
\text { Feed costs } \\
\text { (L.E)/kg weight } \\
\text { gain }\end{array}$ \\
\hline FBS0 & 5365 & 100 & 0.00 & 1.72 & 9.23 & 100 & 0.00 \\
FBS25 & 4940 & 92.08 & 7.92 & 1.64 & 8.10 & 87.76 & 12.24 \\
FBS50 & 4499 & 83.86 & 16.14 & 2.30 & 10.35 & 112.13 & $-12,13$ \\
FBS75 & 4061 & 75.69 & 24.31 & 2.34 & 9.50 & 102.93 & -2.93 \\
FBS100 & 3596 & 67.03 & 32.97 & 2.35 & 8.34 & 90.39 & 9.61 \\
\hline
\end{tabular}

$*$ Feed costs $/ \mathrm{kg}$ weight gain $=\mathrm{FCR} \times$ costs of $\mathrm{kg}$ feed.

Table 7: Local market price (L.E./ton) for feed ingredients used for formulating the experimental diets when the experiment was started (April 2016).

\begin{tabular}{lcc}
\hline & Ingredients & Price (L.E.) / ton \\
\hline & Fish meal & 8500 \\
Yellow corn & & 2800 \\
Soybean meal & 5500 \\
Fermented fish silage (FBS) & 1000 \\
Wheat bran & 2000 \\
Vegetable oil & 8200 \\
\hline
\end{tabular}

\section{REFERENCES}

Abdel-Hakim, N. F.; Bakeer, M. N. and Soltan, M. A. (2001 a). Effect of dietary protein levels on growth performance and pond productivity of Nile tilapia (Oreochromis niloticus), Eel (Anguilla anguilla) and Grey mullet (Mugil cephalus) reared in polyculture system. Egypt. J. Aquat. Biol. \& Fish., 5(4):61-85.

Abdel-Hakim, N. F.; Hussein, M. S.; Bakeer, M. N. and Soltan, M. A. (2001 b). Effect of protein level and stocking density on growth performance of Nile tilapia (Oreochromis niloticus) cultured in tanks. Egyptian J. Nutrition and Feeds 4 (Special Issue)763-780.

Abdel-Hakim, N. F.; Hussein, M. S.; Bakeer, M. N. and Soltan, M. A.(2001 c). Effect of protein level and stocking density on growth performance of Nile tilapia (Oreochromis niloticus) cultured in tanks. Egyptian J. Nutrition and Feeds 4 (Special Issue), 763-780. 
AbouZead, M. Y.; Soltan, M. A. and Ibrahim, M. S. (2008).Effect of replacing Soybean meal by sunflower meal in the diets of Nile tilapia, Oreochromis niloticus. (L.).Proceeding of the $8^{\text {th }}$ International Symposium on Tilapia in Aquacult., 12: 787-799.

Abdella, M. M.; Hamed, M. R.; El-Sayaad, G. A.; Soltan, M. A. and Saudy, A. M. (2008). Replacement of fish meal by cottonseed meal supplemented with vitamine E in diets of Nile tilapia (Oreochromis niloticus). Annals of Agric. Sci., Moshtohor, 46(4):13-24.

AOAC, (1995). In: Cunni, P.A. (Ed.), Official Methods of Analysis of the Association Official Analytical Chemists, vol. $1,16^{\text {th }}$ ed. AOAC International, Arlington, USA, p. 1298.

APHA, (1992). Standard Methods for the Examination of Water and Waste Waters, $18^{\text {th }}$ ed. American Public Health Association, Washington, DC, 1268 pp.

Boyd, D. (1979). Water Quality in Warm water Fish Ponds. Auburn University Agricultural Experiment Station, Auburn, AL.

Brett J. R. (1973). Energy expenditure of Sockeye salmon Oncorhynchus nerka during sustained performance. J. Fish. Res. Board Can. 30:1799-1809.

Cavalheiro, J. M. O.; Oliveira de Souza, E. and Bora, P. S. (2007). Utilization of shrimp industry waste in the formulation of tilapia (Oreochromis niloticus Linnaeus) feed. Bioresource Technology, 98:602-606.

Duncan, D. B. (1955). Multiple range and Multiple test. Biometerics, 11: 1-42.

Espe, M. Sveier, H.; Høgøy, I and Lied, E. (1999). Nutrient absorption and growth of Atlantic salmon (Salmosalar L) fed fish protein concentrate. Aquaculture, 174:119-137.

Fagbenro, O. A. (1994). Dried fermented fish silage in diets for Oreochromis niloticus. Israeli J. Aquacult., Bamidgeh, 46(3):140-147.

Fagbenro, O. A. and Jauncey, K. (1995). Growth and protein utilization by juvenile catfish (Clarias gariepinus) fed dry diets containing co-dried lactic-acid fermented fish silage and protein feedstufus. Bioresource Technology, 51:29-35.

Fagbenro, O. A.; Jauncey, K. and Haylor, G. (1994). Nutritive value of diets containing dried lactic acid fermented fish silage and soybean meal for juvenile Oreochromis niloticus and Clarias gariepinus. Aquat. Liv. Resour., 7:79-85.

Hafez, F. A.; Soltan M. A. and Ibrahim M. K. (2000).Effect of organic fertilization, supplementary feeding and stocking rate on carcass and chemical composition of Nile tilapia and silver carp. Egypt. J. Agric. Res., 78(5):2127-2142.

Hardy, R.W. (2010). Utilization of plant proteins in fish diets: effects of global demand and supplies of fishmeal. Aquacult. Res., 41: 770-776.

Hassaan, M. S. Soltan, M. A. and Abdel-Moez, A. M. (2015). Nutritive value of soybean meal after solid state fermentation with Saccharomyces cerevisiae for Nile tilapia, Oreochromis niloticus. Animal Feed Science and Technology, 201:89-98.

Hernández, C.; Hardy, R. W.; Contreras-Rojas, D.; López-Molina, B.; González-Rodríguez, B. and Domínguez-Jimenez, P. (2014). Evaluation of tuna by-product meal as a protein source in feeds for juvenile spotted rose snapper Lutjanus guttatus. Aquaculture Nutrition, 20(6): 574-582.

Ibrahim, M. K.; Fatma, A. Hafez and Soltan, M. A. (2000). Effect of organic fertilization, supplementary feeding and stocking rate on growth performance of Nile tilapia and silver carp. Egypt. J. Agric., Res., 78 (4):1775-1799.

Jeon, G. H.; Kim, H. S.; Myung, S. H. and Cho, S. H. (2014). The effect of the dietary substitution of fishmeal with tuna by-product meal on growth, body composition, plasma chemistry and amino acid profiles of juvenile Korean 
rockfish (Sebastes schlegeli). Aquaculture Nutrition 20(2):753-761.

Plascencia-Jatomea, M.; Olvera-Novoa, M.A.; Arredondo-Figueroa, J.L.; Hall, G.M. and Shirai, K. (2002).Feasibility of fishmeal replacement by shrimp head silage protein hydrolysate in Nile tilapia (Oreochromis niloticus L) diets. Journal of the Science of Food and Agriculture, 82(7):753-759.

Kompiang, I.P.; Arifudin, R. and Raa, J. (1980 a).In "Advances in fish science and technology" (J.J. Connell. ed.), pp. 349-352.Fishing News Book.Ltd- London.

Kompiang, I.P.; Darwanto, A. and Arifuddin, R. (1980 b).Nutritional value of fish silage. In: J.G. Disney and D. James (editors), fish silage production and its use. F.A.O Fish. Rep. No. 230- pp. 44-47.

Lapie, L. P. and Bigueras-Benitez, C. M. (1992).Feeding studies on tilapia (Oreochromis niloticus) using fish silage. pp. 165-177 In: D. James (ed.) FAO Fish Rep., No. 470, FAO, Rome.

Mach, D. T. N. and Nortvedt, R. (2013). Comparison of fillet composition and initial estimation of shelf life of cobia (Rachycentron canadum) fed raw fish or fish silage moist diets. Aquaculture Nutrition 19(3): 333-342.

Norman, C.A.; Silverside, D.; Hector, D.A. and Francis, S. (1979).Fish silage, Trop. Sci., 21: 221-230.

Nwanna, L.C. and Daramola, J.A. (2001).Harnessing of shrimp head waste in Nigeria for low cost production of tilapia. Pakistan, J. of Nutrition 2(6):339-345.

Oliva-Teles, A.; Gonçalves, P. (2001). Partial replacement of fishmeal by brewers yeast (Saccaromyces cerevisae) in diets for sea bass (Dicentrarchus labrax) juveniles. Aquaculture, 202: 269-278.

Salah Al-Din, S. A. (1995).Studies on unconventional rations in feeding of Nile catfish (Clarias lazera). M. Sc. Thesis. Fac. Agric., Al-Azhar University.

SAS (1996). SAS Procedure Guide "version 6.12 Ed". SAS Institute Inc., Cary, NC, USA.

Soltan, M. A. (2005 a). Partial and total replacement of soybean meal by raw and heat treated linseed meal in tilapia diets. Egyptian J. Nutrition and Feeds, 8(1):10911109.

Soltan, M. A. (2005 b).Potential of using raw and processed canola seed meal as an alternative fish meal protein source in diets for Nile tilapia, (Oreochromis niloticus). Egyptian J. Nutrition and Feeds, 8(1):1111-1128.

Soltan, M. A. (2002). Using of tomato and potato by-products as non-conventional ingredients in Nile tilapia, Oreochromis niloticus diets. Annals of Agric. Sci., Moshtohor, 40(4):2081-2096.

Soltan, M. A.; Hassaan, M. S.; Abdella, M.; El-Syaad, G. A. and El-Ashry, M. A. (2015). Yeast fermented sunflower meal as a replacer for fish meal in diets of the Nile tilapia, Oreochromis niloticus. Egypt. J. Aquat. Biol. \& Fish., 19(2):6572.

Soltan. M. A.; Saudy, A. M. and Fath El-Bab, A. F. (2011 a).Rearing of the Nile tilapia (Oreochromis niloticus) on diets containing cotton seed meal enriched with vitamin E. Egypt. J. Aquat., Biol., \& Fish., 15 (1):89-104.

Soltan. M. A.; Fath El-Bab, A. F. and Saudy, A. M. (2011 b).Effect of replacing dietary fish meal by cottonseed meal on growth performance and feed utilization of the Nile tilapia, Oreochromis niloticus. Egypt. J. Aquat., Biol., \& Fish., 15(2):17-33.

Soltan, M. A. and El-Laithy, S. M. M. (2008). Evaluation of fermented silage made from fish, tomato and potato by-products as a feed ingredient for Nile tilapia, Oreochromis niloticus. Egypt. J. Aquat. Biol. \& Fish.,12(1):25-41. 
Soltan, M. A.; Hanafy, M. A. and Wafa, M. I. A. (2008). An evaluation of fermented silage made from fish by-products as a feed Ingredient for African catfish (Clarias gariepinus). Global Veterinaria, 2(2):80-86.

Soltan, M. A. and Tharwat, A. A. (2006).Use of fish silage for partial or complete replacement of fish meal in diets of Nile tilapia, Oreochromis niloticus and African catfish, Claris gariepinus. Egyptian J. Nutrition and Feeds, 9(2):299-314.

Soltan, M. A.; Ibrahim, M. K.; Fatma A. Hafez and Fath El-Bab, A. F. (2001).Effect of partial and total replacement of fish meal by soybean meal on growth and proximate analysis of Nile tilapia.Egyptian J. Nutrition and Feeds 4 (Special Issue):799-812.

Van Soest PJ.; Robertson J.B. and Lewis B.A. (1991). Methods for Dietary Fiber, Neutral Detergent Fiber, and Nonstarch Polysaccharides in Relation to Animal Nutrition. J. Dairy Sci., 74:3583-3597.

Wassef, E. A.; Sweilam, M. A. and Attalah, R. F. (2003).The use of fermented fish silage as a replacement for fish meal in Nile tilapia (Oreochromis niloticus) diets. Egypt. J. Nut. Feed, 6 (Special Issue):357-370.

Zhou, J. S.; Chen, Y. S.; Ji, H. and Yu, E. M. (2016). The effect of replacing fish meal with fermented meal mixture of silkworm pupae, rapeseed and wheat on growth, body composition and health of mirror carp (Cyprinus carpio var. Specularis). Aquaculture Nutrition.doi: 10.1111/anu.12441.

\footnotetext{
ARABIC SUMMARY

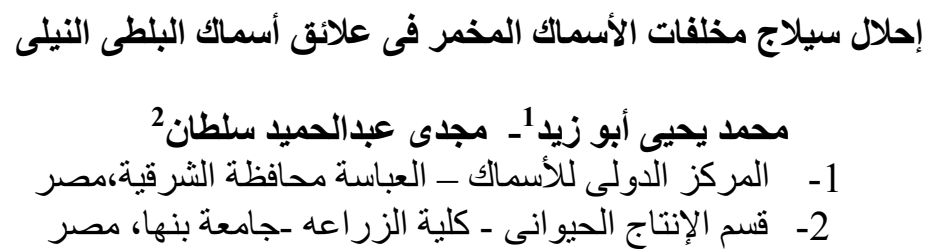

أجريت هذه التجربة بهدف در اسة إمكانية إحلال مسحوق السمك بسيلاج مخلفات الأسماك المخمر كمادة

علفية غير تقليدية فى علائق إصبعيات أسماك البلطي النيلى. ولذلك تم تكوين 5 علائق متساوية فى محتو اها من البروتين (300 جرام/كجم علف) والطاقة (19 ميجا جول طاقة كلية/كجم علف) وتم إستبدال مسحوق السمك

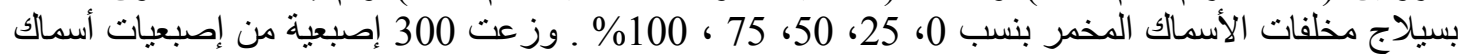

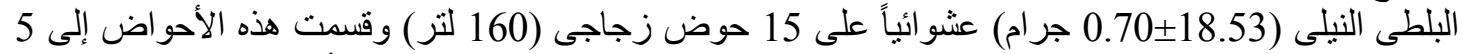

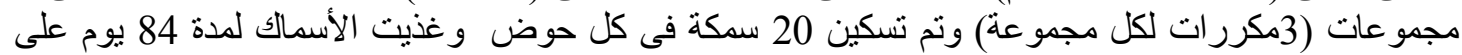
العلائق التجريبية وفى نهاية التجربة وجد أن إستبدال 25\% من مسحوق السمك بسيلاج مخلفات الأسماك المخمر لم

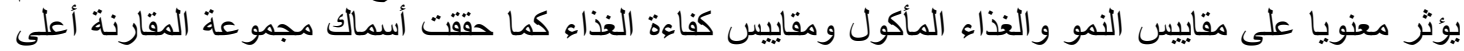

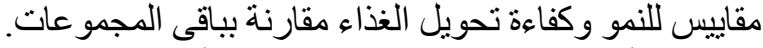

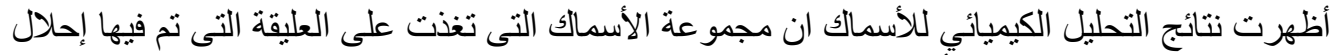
25\% من مسحوق السمك بالسيلاج بها أعلى نسبة بروتين و اقل نسبة دهن ورماد مقارنة بمجمو عة المقارنة وباقى الإنى

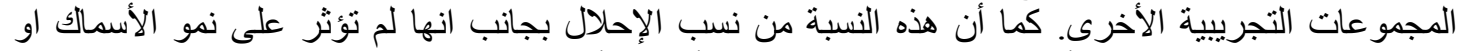
مقاييس الكفاءة الغذائية الإِانها أدت إلى خفض تكاليف إعداد أعلاف أسماك البلطى النيلى بنسبة
} 